\title{
ROMANIAN
}

NEUROSURGERY

\author{
Vol. XXXIV | No. 2 June 2020
}

Contribution of memory evaluation in temporal epilepsy surgery

H. Lelklou,

M. Djellaoui,

H. Si Ahmed,

B. Yakoubi 


\section{Contribution of memory evaluation in temporal epilepsy surgery}

\author{
H. Lelklou ${ }^{1}$, M. Djellaoui ${ }^{1}$, H. Si Ahmed ${ }^{2}$, B. Yakoubi ${ }^{3}$ \\ ${ }^{1}$ Neurologist, Department of Neurology, Bab El Oude University \\ Hospital, Algiers, ALGERIA \\ 2 Neurologist, Department of Neurology, Tizi Ouzou University \\ Hospital, ALGERIA \\ ${ }^{3}$ Neurosurgeon, Department of Neurology, Bab El Oude University \\ Hospital, Algiers, ALGERIA
}

\begin{abstract}
Memory assessment is a crucial step in the pre-surgical assessment of temporal epilepsy. Indeed, it participates to a certain extent in the process of localization of the epileptogenic zone and also makes it possible to anticipate the possible risks of surgical treatment on the memory.

We propose to specify the contribution of memory evaluation in 60 patients' candidates for temporal epilepsy surgery, in terms of localization of the "epileptogenic zone" and in the appreciation of the risk of postoperative memory decline.
\end{abstract}

\section{INTRODUCTION}

During the preoperative assessment, the neuropsychological results, particularly in terms of memory evaluation, participate to a certain extent in the process of localizing the epileptogenic zone. They also make it possible to anticipate the possible risks of a surgical treatment on memory and language.

We propose to specify the contribution of memory evaluation in 60 patients' candidates for temporal lobe epilepsy surgery, in terms of localization of the "epileptogenic zone" and in the appreciation of the risk of postoperative memory decline. We present a case of a patient who has one of the most extended survival lengths reported in the literature despite unusual multisite metastases but deteriorated rapidly due to very aggressive cranium metastasis.

\section{PATIENTS AND METHODS}

\section{Population studied}

We included in our study 60 patients on the following criteria: - Severe, drug-resistant temporal lobe epilepsy (at least 03 major antiepileptics at optimal doses have been tried as monotherapy and in association with an evolutionary decline of at least 02 years);

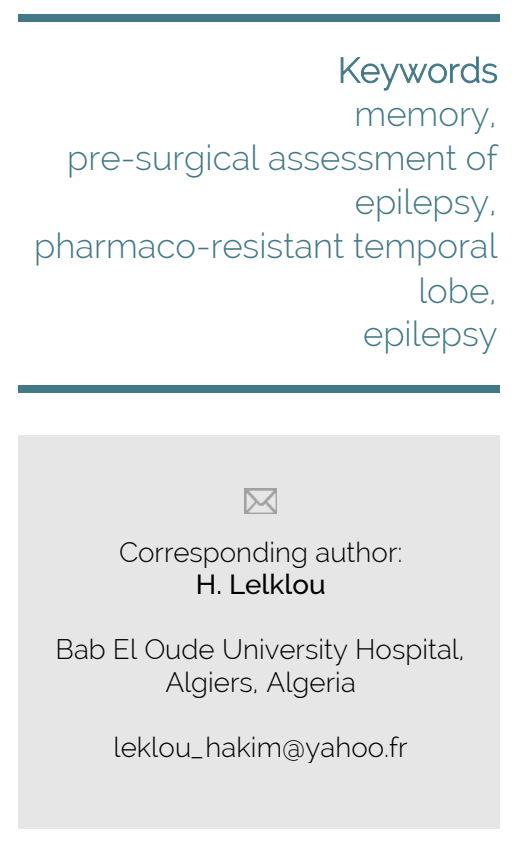

Copyright and usage. This is an Open Access article distributed under the terms of the Creative commons Attribution Non-Commercial No Derivatives License (https://creativecommons org/licenses/by-nc-nd/4.0/) which permits noncommercial re-use, distribution, and reproduction in any medium, provided the original work is unaltered and is properly cited.

The written permission of the Romanian Society of Neurosurgery must be obtained for commercial re-use or in order to create a derivative work.

ISSN online 2344-4959 (C) Romanian Society of Neurosurgery

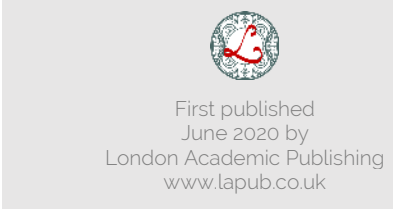


- Age less than 50 years;

- Presence of a temporal lesion on brain MRl;

- Patients whose "epileptogenic zone" is clearly defined at the end of the non-invasive pre-surgical exploration.

- Patients operated on for epilepsy surgery with a regulated temporal lobectomy with broad hippocampal resection.

\section{Applied methods}

- We have studied hemispheric dominance in all of our patients.

-We specified the anatomical lesions found on brain MRI and we separated the patients into two groups (one group with hippocampal sclerosis and another with a lesion of another nature).

- We also specified the lateralization of the "epileptogenic zone" and the extent of the surgical procedure (hippocampus resected or not).

- An overall intellectual efficiency (MMS) and memory (verbal and visual) assessment was performed on all of our patients. The exploration of verbal memory was carried out by the Grober and Buschke test. As for visual memory, it was assessed by the DMS-48 test. The frequency of memory disorders was evaluated pre-operatively in the whole population and was then evaluated according to the associated lesions and the lateralization of the "epileptogenic zone"

- The development of postoperative memory disorders was specified in all patients and was then studied according to the preoperative memory status and the nature of the lesions found on MRI).

\section{Place and period of the study}

The patients were recruited from the Epileptology consultation of the department of Neurology of Bab El Oued University Hospital over a period from January 2010 to December 2019.

\section{RESULTS}

Distribution of patients according to manual dominance:

$100 \%$ of patients are right-handed.

Distribution of patients according to the nature of the lesion found on MRI:

32 patients had hippocampal sclerosis on brain MRI (53\%) and 28 patients had a lesion of another nature (Neuroepithelial dysembryoplastic tumours, Gangliogliomas and finally Cavernomas) (47\%).
Distribution of patients according to the lateralization of the epileptogenic zone:

The lateralization of the epileptogenic zone was on the left (dominant hemisphere for language) in 27 patients (45\%) and on the right (minor hemisphere) in 33 patients $(55 \%)$.

\begin{tabular}{|l|l|l|}
\hline & $\begin{array}{l}\text { Number of } \\
\text { patients }\end{array}$ & $\begin{array}{l}\text { Percentage } \\
\%\end{array}$ \\
\hline $\begin{array}{l}\text { Presence of memory } \\
\text { deficit }\end{array}$ & 39 & 65 \\
\hline $\begin{array}{l}\text { Absence of memory } \\
\text { deficit }\end{array}$ & 21 & 35 \\
\hline Total & 60 & 100 \\
\hline
\end{tabular}

Table 1. Frequency of preoperative memory disorders in all operated patients.

A memory deficit is found preoperatively in $65 \%$ of operated patients.

\begin{tabular}{|l|l|l|l|l|}
\hline & \multicolumn{2}{|l|}{$\begin{array}{l}\text { Epileptogenic zone on } \\
\text { the left (dominant } \\
\text { hemisphere) }\end{array}$} & \multicolumn{2}{|l|}{$\begin{array}{l}\text { Epileptogenic zone on } \\
\text { the right (minor } \\
\text { hemisphere) }\end{array}$} \\
\cline { 2 - 5 } & $\begin{array}{l}\text { Number } \\
\text { of } \\
\text { patients }\end{array}$ & $\begin{array}{l}\text { Percentage } \\
\%\end{array}$ & $\begin{array}{l}\text { Numb } \\
\text { er of } \\
\text { patient } \\
\text { s }\end{array}$ & $\begin{array}{l}\text { Percentage } \\
\%\end{array}$ \\
\hline $\begin{array}{l}\text { Deficit of } \\
\text { the visual } \\
\text { memory }\end{array}$ & 00 & 00 & 33 & 100 \\
\hline $\begin{array}{l}\text { Deficit of } \\
\text { the verbal } \\
\text { memory }\end{array}$ & 27 & 100 & 00 & 00 \\
\hline Total & 27 & 100 & 33 & 100 \\
\hline
\end{tabular}

Table 2. Nature of memory deficit according to the lateralization of "the epileptogenic zone".

All the patients with an epileptogenic zone lateralized on the left (dominant hemisphere) have a deficit in verbal memory and all patients with an epileptogenic zone on the right (minor hemisphere) have a deficit in visual memory.

\begin{tabular}{|l|l|l|l|l|}
\hline \multirow{2}{*}{} & \multicolumn{2}{|l|}{$\begin{array}{l}\text { Group with } \\
\text { Hippocampal Sclerosis }\end{array}$} & \multicolumn{2}{l|}{$\begin{array}{l}\text { Group with another } \\
\text { lesion }\end{array}$} \\
\cline { 2 - 5 } & $\begin{array}{l}\text { Number of } \\
\text { patients }\end{array}$ & $\begin{array}{l}\text { Percenta } \\
\text { ge \% }\end{array}$ & $\begin{array}{l}\text { Number } \\
\text { of } \\
\text { patients }\end{array}$ & $\begin{array}{l}\text { Percentage } \\
\%\end{array}$ \\
\hline $\begin{array}{l}\text { Presence } \\
\text { of memory } \\
\text { deficit }\end{array}$ & 30 & 94 & 09 & 32 \\
\hline
\end{tabular}




\begin{tabular}{|l|l|l|l|l|}
\hline $\begin{array}{l}\text { Absence of } \\
\text { memory } \\
\text { deficit }\end{array}$ & 02 & 06 & 19 & 68 \\
\hline Total & 32 & 100 & 28 & 100 \\
\hline
\end{tabular}

Table 3. Frequency of preoperative memory disorders according to the nature of the lesion.

A memory deficit is found in $93 \%$ of patients with hippocampal sclerosis and only in $32 \%$ of patients with a lesion of another nature.

\begin{tabular}{|l|l|l|}
\hline & $\begin{array}{l}\text { Number of } \\
\text { patients }\end{array}$ & Percentage \% \\
\hline Post-operative decline & 9 & 15 \\
\hline No effects & 51 & 85 \\
\hline Improvement & 00 & 00 \\
\hline $\begin{array}{l}\text { Occurrence of global } \\
\text { amnesia }\end{array}$ & 00 & 00 \\
\hline Total & 60 & 100 \\
\hline
\end{tabular}

Table 4. Postoperative memory status in all operated patients.

Postoperative memory decline is noted in $15 \%$ of operated patients. No cases of global amnesia have been noted.

\begin{tabular}{|l|l|l|l|l|}
\hline \multirow{2}{*}{} & \multicolumn{2}{|l|}{$\begin{array}{l}\text { Group with pre- } \\
\text { operative deficit }\end{array}$} & \multicolumn{2}{l|}{$\begin{array}{l}\text { Groupe without pre- } \\
\text { operative deficit }\end{array}$} \\
\cline { 2 - 5 } & $\begin{array}{l}\text { Number } \\
\text { of } \\
\text { patients }\end{array}$ & $\begin{array}{l}\text { Percentage } \\
\%\end{array}$ & $\begin{array}{l}\text { Number } \\
\text { of } \\
\text { patients }\end{array}$ & $\begin{array}{l}\text { Percenta } \\
\text { ge \% }\end{array}$ \\
\hline $\begin{array}{l}\text { Post- } \\
\text { operative } \\
\text { decline }\end{array}$ & 00 & 00 & 09 & 43 \\
\hline No effects & 39 & 100 & 12 & 57 \\
\hline $\begin{array}{l}\text { Improvem } \\
\text { ent }\end{array}$ & 00 & 00 & 00 & 00 \\
\hline Total & 39 & 100 & 21 & 100 \\
\hline
\end{tabular}

Table 5. Postoperative memory status based on the presence or absence of a preoperative memory deficit.

No patient had a memory decline in the preoperative memory deficit group; whereas a decline is noted in $43 \%$ of the cases in the group without preoperative deficit.

\begin{tabular}{|l|l|l|}
\hline & $\begin{array}{l}\text { Group with Hippocampal } \\
\text { Sclerosis }\end{array}$ & $\begin{array}{l}\text { Group with another } \\
\text { lesion }\end{array}$ \\
\hline
\end{tabular}

\begin{tabular}{|l|l|l|l|l|}
\hline & $\begin{array}{l}\text { Number of } \\
\text { patients }\end{array}$ & $\begin{array}{l}\text { Percentage } \\
\%\end{array}$ & $\begin{array}{l}\text { Number } \\
\text { of } \\
\text { patients }\end{array}$ & $\begin{array}{l}\text { Percentage } \\
\%\end{array}$ \\
\hline $\begin{array}{l}\text { Post- } \\
\text { operative } \\
\text { decline }\end{array}$ & 02 & 06 & 07 & 25 \\
\hline No effects & 30 & 94 & 21 & 65 \\
\hline Improvement & 00 & 00 & 00 & 00 \\
\hline Total & 32 & 100 & 28 & 100 \\
\hline
\end{tabular}

Table 6. Postoperative memory status depending on the nature of the lesion found on MRI.

No patient had memory decline in the hippocampal sclerosis group; while a decline is noted in $25 \%$ of cases in another lesion group.

\section{DISCUSSION}

The high frequency of memory disorders found in our series confirms the data in the literature. Indeed, temporal lobe epilepsy is the greatest provider of memory disorders observed in epileptic patients [1]. Patients with hippocampal sclerosis were more likely to have a preoperative memory deficit than patients with other lesions. These results agree with the data in the literature; indeed, the presence of hippocampal sclerosis, whether right or left, appears to be a predictive factor for the presence of memory impairment in a patient with temporal lobe epilepsy [2;3]. In addition, the severity of the memory deficit appears to be correlated with the degree of neuronal loss of the diseased hippocampus [4]. It has also been shown that when temporal lobe epilepsy is linked to a structural lesion of another nature, disorders of verbal memory are correlated with left hippocampal neuronal loss [5].

In our series, the nature of the memory deficit observed in right-handed patients depended on the side on which the epileptogenic zone was lateralized. Indeed, the deficit concerned in all cases the verbal memory when the epileptogenic zone was lateralized on the left (dominant hemisphere) and the visual memory when the epileptogenic zone was lateralized on the right (minor hemisphere). This observation is consistent with the data in the literature which recognizes a lateralizing value for the memory deficit [6]. Indeed, temporal lob epilepsies concerning the dominant hemisphere are characterized by a deficit in verbal memory $[7 ; 8 ; 2$; 9] and temporal lobe epilepsies concerning the 
minor hemisphere (the right for right-handers) can be associated with a deficit of non-verbal memory $[10 ; 11 ; 12]$.

The risk of a memory deficit after an anterior temporal lobectomy is much greater when the preoperative memory efficiency is normal $[13 ; 14 ; 15$; 16; 17]; This could be explained by the fact that the absence of a preoperative memory deficit suggests that the hippocampus concerned by the excision is still functional.

The data from our study confirm this view; indeed, patients who underwent an intervention comprising a large hippocampal resection with a preoperative memory deficit, did not degrade their memory scores postoperatively. This could be explained by the fact that the preoperative deficit suggests a loss of the function of the hippocampus concerned by the resection.

This favourable postoperative outcome in terms of memory is also noted in patients with hippocampal sclerosis with a correct preoperative memory score. This recalls the favourable prognostic value, in terms of memory, of the presence of hippocampal sclerosis (see above). Indeed, the presence of unilateral hippocampal sclerosis (especially when it is severe) with a correct memory score, is compatible with a loss of hippocampal function compensated by the contralateral side.

Finally, no global amnesia was noted due to the absence of signs indicating a dysfunction of the contralateral hippocampus, such as the case of simultaneous impairment of verbal and visual memory. This notion underlines the major interest of memory evaluation in the context of the pre-surgical assessment of temporal lobe epilepsy surgery.

\section{CONCLUSION}

During the preoperative assessment of temporal epilepsies, the results of the memory assessment participate to a certain extent in the process of localization and lateralization of the epileptogenic zone.

They also make it possible to anticipate the possible risks of a surgical treatment on the memory.

\section{REFERENCES}

1. Rouleau I. La neuropsychologie de l'épilepsie: 50 ans de progrès. Revue de neuropsychologie 2010; 2: 2703271.
2. Hermann BP, Seidenberg M, Schoenfeld J, Davies K. Neuropsychological characteristics of the syndrome of mesial temporal lobe epilepsy. Arch Neurol 1997 ; 54:369-76.

3. Marques CM, Caboclo LOSF, da Silva TI et al. Cognitive decline in temporal lobe epilepsy due to unilateral hippocampal sclerosis. Epilepsy Behav 2007; 10: 477-85.

4. Sallie B. The impact of epilepsy surgery on cognition and behavior. Epilepsy Behav 2008; 12: 592-9.

5. Sass KJ, Spencer DD, Kim JH et al. Verbal memory impairment correlates with hippocampal pyramidal cell density. Neurology 1990; 40: 1694-1697.

6. Henry TR, Roman DD. Presurgical epilepsy localization with interictal cerebral dysfunction. Epilepsy Behav 2011; 20: 194-208.

7. Delanney R, Rosen A, Mattson R, Novelly R. Memory function in focal epilepsy : a comparaison of non surgical, unilateral temporal lobe epilepsy and frontal lobe samples. Cortex 2000; 16:103-117.

8. Hermann BP, Wyler A, Richey E, Rea JM. Memory function and verbal learning ability in patients with complex partial seizures of temporal lobe origin. Epilepsia 1987; 28: 547-554.

9. Selwa LM, Serent S, Giordani B et al. Serial cognitive testing in temporal lobe epilepsy: longitudinal changes with medical and surgical therapies. Epilepsia 1994; 35: 743-749.

10. Alessio A, Damasceno BP, Camargo $\mathrm{CH}$, Kobayashi $\mathrm{E}$, Guerreiro CA, Cendes F. Differences in memory performance and other clinical characteristics in patients with mesial temporal lobe epilepsy with and without hippocampal atrophy. Epilepsy Behav 2004; 5.

11. Helmstaedter C, Pohl C, Hufnager A, Elger C. Visual learning in non-resected patients with right lobe epilepsy. Cortex1991; 27:547-555.

12. Jones-Gotman M. Presurgical neuropsychological evaluation for localization and lateralization of seizure focus. In: Lüders H, Ed. Epilepsy surgery. New York : Rven Press, 1991: 469-75.

13. Baxendale S, Thompson P, Harkness W, Duncan J. Predicting Memory Decline Following Epilepsy Surgery: A Multivariate Approach. Epilepsia 2006; 47: 1887-94.

14. Helmsteadter C, Kurthen M, Lux et al. Chronic epilepsy and cognition : a longitudinal study in temporal lobe epilepsy. Ann Neurol 2003; 54: 425-432.

15. Jones-Gotman $M$, Smith $M L$, Risse $G L$, Westerveld $M$, Swanson SJ, Giovagnoli AR, et al. The contribution of neuropsychology to diagnostic assessment in epilepsy. Epilepsy Behav 2010; 18:3-12.

16. Lee TMC, Yip JTH, Jones-Gotman M. Memory Deficits after Resection from Left or Right Anterior Temporal Lobe in Humans: a Meta-Analytic Review. Epilepsia 2002; 43: 283-91.

17. Rausch R, Kraemer S, Pietras CJ et al. Early and late cognitive changes following temporal lobe epilepsy. Neurology 2003; 60: 951-959. 